\title{
THE KING AND I A MARI KING IN CHANGING PERCEPTIONS*
}

\author{
JACK M. SASSON
}

\author{
UNIVERSITY OF NORTH CAROLINA
}

\begin{abstract}
This presentation reviews the ways scholars have reconstructed the life of one king of Mari, Zimri-Lim, who lived in the middle-Euphrates region in the early eighteenth century B.C.E.
\end{abstract}

THE "KING" ABOUT WHOM I SPEAK lived almost four thousand years ago, and he was not particularly distinguished. He generated no new paradigms for dominion, imposed no dynastic principles, built no enduring monuments, instigated no new social movements of which we are aware, and, thank God, launched no new religions. No poet sang his praise posthumously, and no legend was built around his deeds. ${ }^{1}$ Yet, I would not call him insignificant, if only because in his lifetime many thought he could be their passport to happiness. I want to tell you something about him; but I also want to use him to comment on the drive we share as custodians of the past to bridge gaps and complete stories.

The king of my title is Zimri-Lim, and in the early eighteenth century B.C.E. he ruled at Mari, now just a tell on the right bank of the Euphrates, about fifty kilometers north of the present Iraqi-Syrian border. I first met with Zimri-Lim in the early 1960s. I was a graduate student at Brandeis then and, frankly, I was delighted to learn that although Zimri-Lim was fluent in Akkadian and Amorite, he communicated also in French, the language of his editors. And when I further learned that his

* This is a lightly modified version of the Presidential Address delivered in Miami, Florida, at the 207th meeting of the American Oriental Society, March 25, 1997. I have omitted levities that play on the conjunction of the title of my address and those of a well-known musical and movie.

Unless otherwise indicated, all abbreviations follow the $C A D$.

I am grateful to Maynard Maidman for editing the essay.

1 This was the case of Samsu-iluna a generation later; see Lambert 1991. Zimri-Lim did indeed inspire his poets to create a highly elaborate "epic," just after his early successes against Benjamin tribes. Although it is the earliest we know of a literature much favored later on, it is not likely that Mari's court poets originated the genre. This epic is still not fully published; for the most recent statement about it, see Durand 1993: 51-52. On Zimri-Lim's fate, see also note 21, below. queen came from my own birthplace, Aleppo [Halab], he seemed so much like folks with whom I grew up that I could not imagine him keeping any secrets from me.

In those days, I felt certain that my upbringing in Aleppo and Beirut gave me a special entry into the past. Lexical affinities fed this allusion. Had I not prepared for life as a țupsarrum, Akkadian for scribe, when as a child in Beirut I wrote on the board with a tabshur, a piece of chalk? Was I not instructed in 'adab, "culture," just as ancient scribes apprenticed in their edubba-schools?

There were other, seemingly more compelling, epiphanies, such as when reading about legal procedures from Mesopotamia brought to my mind the saga of a distant aunt sent out naked from the divorce chamber. ${ }^{2}$ Or when, upon learning that Old Babylonian grooms presented their brides handsome gifts heaped on platters, I recalled the swèni ("trays"), similarly lavish celebrations (Greengus 1966: 59-61).

Such conjunctions of words and practices were, of course, as false as they were benign, with only the same approximate sound or landscape in common; yet through them, I sought reciprocally to quicken the life of two lifeless cultures, one Mesopotamian and remote, the other Judaeo-arabic and surviving now only between the covers of Claudia Roden's highly recommended recent book (1996) on Sephardi food. But Western scholarship, alas, distances researchers from their subjects, and the illusion could not long endure. Still, as the world I was studying became more remote, Zimri-Lim was there to ease the parting.

The French were governing Syria when, in the late 1920 s, they began to excavate Tell Hariri, initiating the resurrection of a town whose death was rehearsed in the records of Hammurabi of Babylon. Within a decade, the broad outline of Mari's history had been sketched.

\footnotetext{
${ }^{2}$ For similar practices in antiquity, see van der Toorn 1996: 45-47.
} 
The city has had roots deep into the fourth millennium and its rulers had actively shaped third-millennium regional history. But its archives shed the brightest light on one century of the Old Babylonian period that ended around 1760. A series of articles published before World War II provided basic information about Zimri-Lim. In 1936, François Thureau-Dangin established Yahdun-Lim as the king's father and proved that he was Hammurabi's contemporary (Thureau-Dangin 1936). ${ }^{3}$ In 1937, Georges Dossin, who headed the Mari epigraphic team until 1981, quoted a passage that ranked Zimri-Lim very high among the power brokers of his day (Dossin 1937: 17-18). That same year, Thureau-Dangin cited a text (later fully published as $A R M 13$ ) proving that during a long interval between Yahdun-Lim and Zimri-Lim, Mari was first ruled briefly by a shadowy figure named Sumu-Yamam and then by Yasmah-Addu, who was placed on the throne by his father, a grizzled warrior named Šamši-Addu (Thureau-Dangin 1937). When in 1939 Thureau-Dangin published clay labels bearing Hammurabi's date-formulas, Zimri-Lim's position as Mari's last ruler was confirmed (Thureau-Dangin 1939).

So as the storms were gathering over Europe, much had come to be known about Zimri-Lim. Archaeological reports were proving how exceptional was his palace. Scholars knew about his lineage and they recognized that his rise to the throne was turbulent, that he enjoyed prestige in his own days, and that his end was violent. Still lacking was information about his apprenticeship, the length of his rule, and details of his personal life. It was not until 1949 that Dossin established the Aleppo origin of Queen Siptu. Soon afterward, he quoted a letter in which Zimri-Lim reminded his Aleppo father-in-law of the aid he gave in regaining the Mari throne (Dossin 1952; full edition 1973: see Appendix).

With these added details, a biography of Zimri-Lim was emerging that was surprisingly satisfying and complete, although it was commonly delivered as a page from period history. This reconstruction was shaped by a wide cast of scholars, including such A.O.S. stalwarts as William Albright, Albrecht Goetze, and Hildegard Lewy;

\footnotetext{
${ }^{3}$ Parrot, who excavated Mari into the mid 1970s, tells how the great Assyriologist Thureau-Dangin jumped with excitement on finding a letter Hammurabi of Babylon sent to Zimri-Lim (Parrot 1966: 9). It should be recalled that in 1936 Hammurabi was the patron saint of Assyriology, not just because of his law "code," then deemed the earliest in history, but also because of his successful empire building which, in the opinion of many scholars who then commented on Genesis 14, brought him into conflict with the Hebrew patriarch Abraham.
}

but I give you its gist from the pen of André Parrot, the man who first excavated Mari.

In a Séance publique annuelle des cinq académies, Parrot sketched the life of a chief of state (Parrot 1966). To Parrot, the Mari documents supplied us with the name of the ruler Hammurabi boasted of defeating when, in his thirty-fifth year-name, he recorded the destruction of Mari. The victim was Zimri-Lim, and he had had a tough life. Surviving his father's assassination, the young prince found refuge in the Aleppo of King Yarim-Lim. His exile there ended twenty years later, when he defeated the usurper Yasmah-Addu. Then, for over thirty years he ruled from his palace, a city within a city, where every sector had its proper function, the whole protected by massive walls. For Parrot, Zimri-Lim was an enlightened despot, a "powerful and noble chief of state," who tirelessly prodded administrators to fulfill their duty (p. 11). His power was absolute, with political as well as sacerdotal dimensions; but he remained accessible to petitioners, visitors, and tribal leaders. Among them, Parrot imagined, were Benjaminite chieftains, kin to Terah and Abraham, in transit toward Haran (p. 8). To escape, the king would hie to a corner of the palace. (To his credit, Parrot avoids the term "harem.") There, among other wives and concubines, he would find Siptu, a queen capable of writing one of the most ardent love letters from antiquity.

But virtue and hard work (as we all know) rarely protect from covetous neighbors. For Parrot, Hammurabi of Babylon was a Machiavellian ally, striving for hegemony. Mari stood in the way and was conquered. The victorious Babylonian humiliated Zimri-Lim by forcing examination of his correspondence. Stung, Zimri-Lim tried to break Babylon's yoke, but failed. Hammurabi turned implacable. Mass executions took place outside the city walls. As columns of slaves made their way to Babylon, Hammurabi razed the palace and burned it. Parrot did not speculate on Zimri-Lim's fate, but opined that in the looted Mari palace just enough was left behind to attest to ZimriLim's power and nobility (p. 11).

Given its public setting, Parrot's presentation was bound to be hyperbolic. Yet, his story was but a less obsessively academic version of what then obtained in learned journals. What he offered, of course, is not history, even by Voltaire's minimalist definition of history as "a panorama of crimes and misery." And neither is it sober biography, because it lacks the self-conscious compromises with historical methodologies that normally occur

\footnotetext{
4 "En effet, l'histoire n'est que le tableau des crimes et des malheurs ...” (L'Ingénu [1767], ch. 10).
} 
in the academic version of that genre. But it is history as moral drama, a decent, even commendable, exemplum of a responsibly held kingship. And Parrot crafted it with balance and empathy, bracketing a whole life within two defining massacres; the first, initiating Zimri-Lim's exile, explains his resolve and teaches the value of fortitude; the second, ending his reign, warns about villainy, but also suggests the mystery of theodicy. It is therefore reminiscent of the melodramatic biblical portraits of Moses, Jacob, and David, the lives from Plutarch and Suetonius, the tarjamas about learned Muslims, and countless medieval lives. What they all share is a plot that follows the subject from youth to death, even when offering details selectively. The plot itself underscores the singularity of the subject's achievement; and in doing so, it makes frequent yet unobtrusive conjunctions among biographer, subject, and audience.

I feel sure that Parrot, consciously or otherwise, accented these aspects of the paradigm, not because they would confer antiquity or nobility on his story, but because of the uncanny, déjà entendu familiarity of the pattern. You should therefore not be surprised to find the story, with its echoes of the "juste souffrant" theme, repeated more or less whole in some of the latest and most sophisticated rehearsals of what went on in Old Babylonian Mari (Kuhrt 1995: 98-100; Klengel 1992: 55). Even Parrot's reluctance to speculate on Zimri-Lim's personal fate was a positive touch, for it fed our hopes that among the unpublished documents evidence for a merciful end to Zimri-Lim's life would yet be found. On this expectant note, let us shift to the next phase of studies on Zimri-Lim, which I place between the early 1950s and the mid-1970s. It is during this phase that the king and I had our closest encounters.

Volumes of edited documents from the reign of ZimriLim had begun to appear in a cluster during the early 1950s. Dossiers of administrators, such as provincial governors, palace stewards, and heads of storehouses, were joined by a collection of juridical documents and by four large volumes containing hundreds of economic documents recovered from specific rooms of the palace..$^{5}$ However, the pace of publication was deliberate, more

\footnotetext{
${ }^{5}$ A full list of the published series, containing volumes of cuneiform copies and of their transliterated and translated treatments, is available in Heintz et al. 1990 (with supplements, 1992-96), and in Pardee 1984. The documents in these volumes enlarged the vision that scholars had of the Old Babylonian period, its history and culture. Many biblical scholars felt encouraged to use Mari in reconstructing the early phases of Hebraic history. Also published at this time was ARMT 15 (1954), a major tool for accessing Mari's lexical and onomastic
}

like an invitation to hors d'œuvres than to a full course meal. Yet the plan worked, for when I first inspected the archives in the early 1960s, almost every other Assyriologist and nearly all prominent biblical scholars had something to say about Mari and its archives.

Zimri-Lim's story fared pretty well during this phase. Of course, no one was actually producing a full-blown biography then; but because the documentation was largely the private archives of a city's ruler, most Mari contributions included imaginative consolidations of fragments of biographies, of Zimri-Lim and of the leaders coming into contact with him. Still, the testimony of published economic documents did sharpen the crucial issue of Zimri-Lim's chronology.

From a number of non-Mari sources, early on it was obvious that Zimri-Lim's reign must be sandwiched between the death of Samši-Addu and Hammurabi's capture of Mari, an interval of fifteen to twenty years. In 1950, however, Dossin published thirty-two formulas that Zimri-Lim's scribes used for dating administrative texts. How to reconcile the discrepancy between a reign of twenty years, at most, and thirty-two formulas became a hot topic of debate. Because philologists, then as now, are more likely to question the competence of living colleagues than the motivation of dead scribes, hunkering down and letting Zimri-Lim rule thirty-two years was a valid option for many. William Albright, for example, did so, blaming the inconsistency on the Middle Chronology (Albright 1968: 232-33). In an article that still stuns by its confidant manipulation of historical fragments, Sidney Smith had Zimri-Lim ruling in the Aleppo region before bringing his archives with him to Mari (Smith 1957: 160). ${ }^{6}$ For Hildegard Lewy, Zimri-Lim kept his throne as Hammurabi's vessal for two decades until Mari was destroyed by the Kassites. ${ }^{7}$

Zimri-Lim survived well these doubts about the extent of his career. For one thing, without a chronological sequence for the available date formulas, no meaningful narrative could be constructed, however many years Zimri-Lim ruled and no matter how chatty were palace records on the movement of people and property in and out of Mari. This lack of chronology also compromised establishing a context for the letters, even when they

wealth. More so than any other contribution, this volume kept Mari research within reach of a broad range of scholars.

${ }^{6}$ Even more striking for its integrated vision of the past is Smith's study of 1940, where he had premonitions about these developments (1940: 32-34).

${ }^{7}$ Lewy 1962: 266 and the arguments detailed in Lewy 1967: 25-26. For other good discussions of the dilemma that were then current, see Rowton 1962: 41 and Huffmon 1965: 8-9. 
alluded to similar events. To compensate for this lack of chronology we used logic-not an especially fruitful way to connect with the past. For example, when two dossiers showed that the same individual held two administrative posts with distinct functions, we first judged which of the posts was more prestigious and then used the alleged rise in prestige to place the dossiers in a chronological sequence. Amazingly enough, this circular reasoning did not compromise the portrayal of Zimri-Lim; but rather than completing him in silhouette, we worked best at giving him a personality.

The letters recording exchanges between Zimri-Lim and his subordinates brought out facets of his character. True, we lacked passages in which he pondered his calling or mused about the worth of a life of constant combat. We lacked the perspective to judge the credibility or trustworthiness of the king's correspondents. And we had not yet begun to decipher the conventions regulating Old Babylonian epistolary. How much exaggeration was acceptable when reporting events? How much misquoting of conversations or letters was tolerable? How much distortion was allowable when shuttling information from one language to another? How was the reporting of hearsay codified? And so forth. (See Sasson, forthcoming.)

Despite all the shortcomings, from these letters we were able to penetrate Zimri-Lim's personality. From witty or proverbial statements attributed to him we could decide that his sense of humor was more subtle than crude. We learned also that he was not without vanity, for he pestered his valets for specific cuts of garments and reacted with fury when feeling ignored. He was not without curiosity, for we have records of extensive visits beyond his kingdom. He had a large appetite for details of government, constantly soliciting answers to unsatisfied questions. But he also suffered well the internal bickering and scandalmongering of bureaucrats vying for his attention. It is obvious, too, that Zimri-Lim was a pious, god-fearing man, prompting his staff to proceed with religious ceremonies and requesting to be kept abreast of the latest messages from the gods. Yet, he was not beyond whining, especially when asked for objects he did not wish to give up. He also seems to have had self-doubts. Psycho-historians will no doubt delight in reading a more recently edited letter Zimri-Lim wrote to his shrink (in this case, a respected diviner). In it, the king reported a dream he had had, in which the wife of his youth, Dam-hurāṣi, was kidnapped by Sutu-nomads. ${ }^{8}$

${ }^{8}$ ARM 26225 (the name of the writer is lost):

I have listened to the letter my lord sent me. My lord had written me: "The dream I had is worrisome. I fear that
But nothing has given us a more personal access to Zimri-Lim, or perhaps any ancient monarch, than Dossin's 1967 publication of letters exchanged with or among the women of his palace (Dossin 1967; see Dossin and Finet 1978). My own entry into Zimri-Lim's family began about this time, when developing a prosopography for elite women. It became clear that Zimri-Lim had no acknowledged brothers and no sons who, it seems, lived into adulthood; so his family consisted of a large number of aunts, sisters, wives, daughters, and concubines, and he was constantly bombarded by their letters. Some of these letters were couched in an exceptionally intimate tone or dealt with remarkably personal matters, such as how to announce to a king that his infant daughter is dying (ARM 26 222). But many more letters either pressed advice on him or forced him into emotionally wrenching decisions. How Šiptu evolved from being the latest of the king's brides to a trusted counsellor and an intermediary between him and the gods is just one story emerging from this correspondence (for now, see Sasson 1994). Several more could be told about the marriages of daughters to allies and vassals (Lafont 1987). None is more bathetic than the drama of two sisters wedded to one vassal, Haya-Sumu of Ilanșura. Unfolding over half a dozen years, this story ended with the triumph of one sister, the mental deterioration of the other, the souring of relations with a trusted ally - but, we hope, also in a wiser father and king (Durand 1984a: 162-72). Yet, even as brushstrokes were filling in this portrait of an able, albeit harried, ruler and a family man, forces were at work to compromise, indeed to reverse, its completion.

Sutu-nomads may capture Dam-hurāṣi and you too, asserting, 'as long as you don't give us back our homes, we will not release them!'” This is what my lord wrote me.

As soon as I heard my lord's letter, I summoned the diviners and posed the following query saying: "My lord forcefully wrote to me; what do you advise?" this is what I asked them, and they gave me the following answer... (rest fragmentary).

The dream seems to have occurred about the time Siptu's authority over palace management seems most conspicuous, after the deaths of Addu-duri and Inibšina, respectively the aunt(?) and sister of the king. Dam-burâși herself continued to reign, mostly from the Terqa palace, throughout Zimri-Lim's reign. The letters she writes tend to be insipid, sending greetings and requesting news ( $A R M \quad 10 \quad 62-72$ ). The latest administrative document known to me that mentions her is from 12.v.ZL11' (ARM 25 394, "Gold and silver, for the boat of the god Sin, belonging to Dam-hurāși). In FM 274 (Groneberg 1994), the king requests from Mukannišum a refurbished palanquin imported from Qatna, belonging to Dam-burāṣi. 
The first threat came innocently enough, in a 1978 article of Maurice Birot. Assisted by Jean-Marie Durand, Birot made a complete inspection of the vast administrative archives and placed sixteen of Zimri-Lim's thirtyfive year-date formulas in chronological order. In all, these sixteen formulas covered twelve consecutive years of rule, demonstrating that Zimri-Lin's scribes had no qualms about using multiple date formulas for one year of the king's rule. Within months, Moshe Anbar (1979) was able to claim that Zimri-Lim had ruled just fourteen years, so just two more than Birot's reconstructed sequence. Others, including myself, were willing to leave him on the throne a couple of years longer (Sasson 1980: 7). In effect, what the previously known synchronisms had suggested long ago - that Zimri-Lim could not possibly have ruled as many years as the number of his year-date formulas-was now corroborated.

Birot's exercise had immediate consequences on the neat life we had worked out for Zimri-Lim. Something like an implosion overtook it, and the reign that had unfolded over a relatively broad span, was now contracting to less than half its former length. Within a decade, Zimri-Lim was also to acquire new origins which, as we shall see, also meant that he was to forfeit control of his own destiny. Here is what happened.

The recovery of a sequence for the year-date formulas of Zimri-Lim allowed us to place hundreds of dated documents in a orderly march, from practically one end of Zimri-Lim's reign to the other, in effect affording us a glimpse of palace operation for over four thousand days. ${ }^{9}$ Administrative activities and events could now be set in sequence, each having its own background and aftermath. When augmented by details drawn from relevant, normally undated, letters, the combination of information can prove very instructive when constructing events. Zimri-Lim's marriage to Siptu of Aleppo is a good illustration of the new opportunity.

When in 1981 Durand took over publication of the Mari documents from Dossin, he assembled an energetic team of scholars and within a few years of his appointment the floodgates suddenly burst open. Documents, new and reedited, began to spill forth, in copies, translations, and extensive commentaries. So great and sudden was the deluge that as of today few scholars beyond this team have participated consistently in the major historical reassessment of the archives and their import.

\footnotetext{
9 The records are not evenly distributed. For some days, particularly during the mid-portion of Zimri-Lim's reign, records could be scant or even totally lacking. At other moments, we may have half a dozen records for a single day.
}

Among the tablets Durand published was a series of letters sent to Mari by Asqudum, a trusted confidant of the king. Asqudum was sent on a mission to fetch an Aleppo princess for his king, and the letters he posted while en route have a story to tell that matches the Bible's drama about securing a bride for Isaac. But the posting also reveals that the nuptials occurred, not when Zimri-Lim was in exile, but up to three years after he had mounted Mari's throne. By then, Zimri-Lim was a mature man, with many wives, and with daughters whom he had wedded to local rulers before he captured Mari (Durand 1988a: 95-117). As to the kvetchy letter Zimri-Lim wrote his father-in-law to complain about the latter's withdrawal of support, it assumes a different meaning when deciphered through the political etiquette of the day. Vassals, petitioners, or recently enthroned rulers politely called themselves "sons" of more senior rulers and might even give them credit for their own rise, whether deserved or not. ${ }^{10}$ So, with a better explanation of how Siptu came to Mari and a political exegesis for the vocabulary he used when writing Yarim-Lim, there was no real ground to have Zimri-Lim escaping to Aleppo after the death of his father, Yahdun-Lim. But soon, there was to be more unsettling news.

In the early 1980 s, Dominique Charpin, a member of the new team, discovered the fragmentary imprint of a cylinder seal belonging to Zimri-Lim on an envelope of an unsent tablet, written at the dawn of the king's reign (Charpin 1992a). ${ }^{11}$ Unlike two other commonly used cylinder seals that named Yabdun-Lim as the king's father, this one began with the element "Hadni-," the second portion containing a now effaced divine name. My own notion is that the initial element is based on the same Semitic root $\left({ }^{*} \mathrm{HDN}\right)$ of the more formal throne-name "Yabdun-Lim" (Sasson 1984: 115-16). In fact, there is nothing in the records to suggest that anyone, including certified Zimri-Lim haters, ever claimed a different paternity for him. To the contrary, when old-timers drew lessons for Zimri-Lim's benefit by recounting his father's deeds, they spoke of Yahdun-Lim; and when the gods lectured Zimri-Lim about proper piety, they made a sermon out of Yahdun-Lim's behavior.

But the discovery was nonetheless troubling, and it sent Charpin and Durand searching for Zimri-Lim's

\footnotetext{
${ }^{10}$ See Appendix, "Kinship Terminology and Political Metaphors in Two Mari Letters" (A.1101 and A.1153).

11 The discovery was made in the early 1980 s and its implications exploited in Charpin and Durand 1985. The letter to Tiš-ulme, on the envelope of which was rolled the seal giving Hadni-[ . . ] as Zimri-Lim's father, is now retranslated in Durand 1997: 386-88 [no. 247].
} 
lineage. And when they located it, they used their finding not merely to amend the biography of Zimri-Lim or to draft around it a new page of the Old Babylonian period, but also to generate a new paradigm for Old Babylonian History. Given the flood of new information from the Mari archives, it was tempting to do so, for the vastly increased textual corpus published under Durand's authority has deepened our acquaintance with previously known Mari personalities, allowing us a better grasp of their careers and responsibilities as they reported on passing caravans, burst ditches, marauding lions, pesky bandits, savage plagues, nasty weather, beastly locusts, demeaning slanders, and worthy accomplishments. The documents have also fleshed out episodes in Zimri-Lim's reign that had heretofore been barely known, such as the redemption of captive tribesmen, the taking of the census, the royal state visits to and from Mari, and so forth.

But what the last decade of publication has illumined most brightly is the world of statecraft and diplomats. Zimri-Lim posted his men in the capitals of vassals, to act as ambassadors, as spies, and, when they headed military garrisons, also as unsubtle enforcers of Mari's political objectives. Moving often in teams to major power centers, these diplomats had seemingly instant access to scribes, and when they wrote, they did so individually, massively, and often. Even when drafted under short notice, their letters ought not to remind us of the comparatively anemic sort from contemporaneous Mesopotamia often found in the Altbabylonische Briefe series still coming out from Brill of Leiden. The Mari examples can contain dozens of long lines and, in rhetoric, can match the best of biblical prose, full of vivid phrasing, lively pacing, and a terrific sense of structure. Diplomats could be incredibly gabby and anecdotal, even titillating, as when they dispensed juicy gossip about the wives of their hosts. And, as a diplomatic mission often included more than one person, each of whom could report separately to the king, we can have a wonderful time collating different statements about the same phenomenon from which to reconstruct events as well as to recover insights into Mari personalities. Yet, richly detailed though they may be, these texts cannot be left to speak for themselves, for they report hearsay, rumors, and misunderstandings as often as solid information. A great challenge, therefore, has been for us to learn how to use them, especially in what they have to say about the world in which Zimri-Lim operated (Sasson, forthcoming).

The most striking consequence of this cornucopia of new material is the shifting of focus from internal Mari affairs to those unfolding in diverse principalities of the Balib and Upper Habur areas and in the capitals of regional kingdoms. In Zimri-Lim's day, the area was a ver- itable Serengeti Plain, where predators were most deadly when operating in packs and their prey most vulnerable when striking out on their own. Imagine it, if you like, as a world full of Saddam Husseins and his charming kinfolk. While "house," that is, "dynasty," was a metaphor commonly invoked among them, except for such powers as Babylon and Ilanșura, violent change of leader was the rule at most centers, and it is increasingly evident that Old Babylonian Mari was just another illustration of this condition. Kingdoms such as Kurda, Andarig, Ašlakka, Ašnakkum, and Karana behaved like amoebae, changing shape and size at will. Kings were perpetually locked in a lethal version of musical chairs, such that to label some of them "usurpers" and others "legitimate heirs" is to be superfluously fussy about pedigree. Thus, Kurda had four kings in ten years; the same for SubatEnlil, alias Šebna. Talhayum was more stable, with only three kings in the same period; but Ašnakkum had five rulers in less than five years.

These shifts in leadership seem excessive-even when measured by Italian standards! In these contexts, an oftcited statement made by a Mari official proves ironic. Itur-asdu had written sometime during Zimri-Lim's sixth year: "No king is truly powerful just on his own: ten to fifteen kings follow Hammurabi of Babylon, as many follow Rim-Sin of Larsa, as many follow Ibal-pi-El of Ešnunna, and as many follow Amut-pi-El of Qatna; but twenty kings follow Yarim-Lim of Yambad" (A.482: 22-27, cited from Dossin 1938: 114). Within a few years of that letter, this assessment would not be true for half of those mentioned, as well as for Zimri-Lim himself, whose fate as king becomes our next concern.

Writing a series of seminal articles individually or jointly, Charpin and Durand have proposed that ZimriLim was not a son of Yabdun-Lim. They have suggested, rather, that his father was a Hadni-Addu, possibly a brother of Yabdun-Lim, and his mother was Addu-duri, a woman who played a significant role in palace affairs until her death around the seventh year of her son's reign. This hunt for origins may seem marginal to the wideranging and brilliant effort the authors expend on reconstructing Old Babylonian Mari; but in fact it has proven protean, generating, over the course of two decades of intensive and ongoing labor on Mari's archives, a veritable philosophie d'histoire, epitomized by a series of conflicts, progressively more universal in significance, pitting cultures -indeed ways of life-against each other (see recent overview in Charpin and Durand 1991).

On the basis of suggestive but indirect evidence, Charpin and Durand propose that Zimri-Lim belonged, through his father, to a confederation of Amorite tribes, the Bensim'al, roaming on either side of the Euphrates, 
but especially within the Habur triangle. Through his mother, however, Zimri-Lim was also a Benjamin, the scion of a second Amorite tribal confederation spread across the heart of the middle Euphrates. Zimri-Lim is said to have likely lived his youth in the Karkemish area, a Benjamin stronghold, but where the Bensim'al had made some inroads (Durand 1990a: 48 n. 48; Durand, forthcoming).

This split in ancestry proved critical, and its impact is sharpened by the location of Mari, the city he had conquered. In his early days on the throne, Zimri-Lim was busy trying to put a stop to the internecine hostility of these two Amorite branches, and he succeeded by forcing the unruly Benjamin tribes to come to terms with him. However, Zimri-Lim's capital, Mari, also sat at the junction of two major cultures. One of them was West Semitic and Amorite, centering on Aleppo and Babylon. These kingdoms had grasped power relatively recently, but they were relatively pacific in disposition. The other culture deemed itself heir to the great East Semitic and Akkadian dynasty of Sargon, and it was championed by such bellicose states as Ešnunna. ${ }^{12}$ Zimri-Lim had experienced Ešnunna's militancy first hand during the early years, especially when it gave aid and comfort to the Benjamin tribes. But in the second phase of his rule, although he was torn between his allegiance to the two polar cultures that had merged in Mari, Zimri-Lim eventually concluded a peace with Ešnunna. It turned out to be a "cold" peace. ${ }^{13}$

But graver danger was lurking. Elam, located in a region of what we now call Iran, had always been an éminence grise, balefully watching events to its west. Its people were not Semites, its mores were distinctive. Its leaders, arrogant and aggressive, can be justly labeled empereurs. In this phase of Zimri-Lim's reign, Elam felt ready to play a more active role in the region. It raided and destroyed Ešnunna, an undertaking thoughtlessly assisted by the Amorite powers. The success only whetted Elam's appetite. Its emperor sought access to the Mediterranean and plotted with Qatna far to the west. But a nationalist fervor gripped the Amorites. Banding together in a holy war, Aleppo, Babylon, and Mari stopped Elam in its tracks. Charpin and Durand readily make parallels

\footnotetext{
12 The view is given in a number of articles, most sharply presented in Durand 1993: 47. For bellicose vs. pacific, see Durand 1992b: 99, 114f., 123f., but also Charpin 1992b.

13 Although Yahdun-Lim may have been a client of Ešnunna, Zimri-Lim himself fought at least twice with this state, the earliest occasion, around ZL2'-3', leading to a peace accord in the following year, see Charpin 1991: 162.
}

with the drama that unfolded over a millennium later, when another threat from Persia likewise quickened ethnic solidarity - this time, across the Hellespont. ${ }^{14}$

I have assembled this sketch from a mushrooming bibliography of densely packed studies in which the events described are supported by publication of documents, partially or in full. Yet, it cannot be said that the vision informing this construct is deeply embedded in the documentation; rather, for rationale, it appeals to geopolitics and to power vacuums, and for motivation, it depends on ethnic solidarity and control of trade routes. These elements undoubtedly do play a role in shaping history; but I keep in mind that it is not easy to infer them from so restricted a palace archive, where letters were drafted largely to reach a specific point of view, where "trade" was but a euphemism for rulers recycling gifts among themselves, and where exchange of valuables among the elite was regulated less by market forces than by custom, honor, and fear of scandal. ${ }^{15}$ So while I find it stimulating that the records of one city-state are used to recover historical movements that span centuries, I

14 Durand 1992a: 42, "In ne faut pas hésiter à «dramatiser» les faits et, même si le terme n'est pas employé, parler de «guerre sainte». L'ensemble du proche-orient a dû alors partager sur la question fondamentale de se soumettre ou non à l'Élam." For a succinct overview, see Durand 1995: 471-75 and Durand 1990b: 104.

15 To receive or give lesser gifts than was demanded by rank was an insult; the more so when the gifts were presented publicly. The parade example of royal pique is in a letter ( $A R M$ 520 ) meant to reach Išme-Dagan of Ekallatum. It was sent by Išhi-Addu of Qatna:

This matter is not for discussion; yet I must say it now and vent my feelings. You are the great king. When you requested of me 2 horses, I had them conveyed to you. But as for you, you sent me just 20 pounds of tin. Undoubtedly, you could not be honorable with me when you sent this paltry amount of tin. By the god of my father, had you planned sending nothing at all, I might have gotten angry (but not felt insulted).

Among us in Qatna, the value of such horses is 10 pounds of silver. But you sent me just 20 pounds of tin! What would anyone hearing this say? He could not possibly deem us of equal might. ...

The point being made is that the tin Išhi-Addu received is worth less than 2 pounds of silver, that is, one-fifth the value of the horses. Whether or not the price of the horses was realistic is another issue. See also A.877 about an unacceptable exchange of wine, Charpin and Ziegler 1997. 
think that these documents carry still more conviction when they help us detail the actions, reactions, and inactions of the ruling elite during a comparatively restricted span of time. And when these archives are as rich as those in Mari, there is in them such a density of action and actors that we can approximate the "thick description" of a culture that several historians have achieved recently in the study of medieval Europe.

Thus far, I have focused on Zimri-Lim and on some of the ways he has been perceived since the day he was resurrected. But because this presentation is also about a noble urge to bracket stories by giving them not just beginnings but also ends, please indulge me a bit longer as I pursue the last phase of the Zimri-Lim story.

We have seen that, until recently, the accepted image of Zimri-Lim was that of an honorable king, wronged by his ally, the ambitious Hammurabi. This conception was bolstered by letters in which Zimri-Lim asked his diviners to ascertain Hammurabi's intentions and in which Babylonian treachery was prophesied. Archaeology has shown that the destruction of Mari was unusually deliberate. The palace was emptied and set on fire. After it was burnt, whatever remained standing was methodically torn down, so that no one could think of living there, even as a squatter (Margueron 1990: 423, 431).

For Durand, however, the savage sacking of Mari reflected Hammurabi's anger. During his last year of rule, when Zimri-Lim failed to obtain release of troops he had sent to Babylon, he broke his oath to Hammurabi and allied himself with the despised Ešnunna. In effect, Zimri-Lim was backsliding, reverting to choices his dual heritage and responsibility had forced on him. Durand interprets a number of documents as testifying to a Babylonian march against Mari and quotes a sensational note in which Hammurabi, in a white rage, swore to bring Zimri-Lim to his knees. ${ }^{16}$

${ }^{16}$ A.2962. The text was edited in Durand 1992a: 47-49, and translated in Durand 995: 473 (slightly differently), 1997: 45152 (no. 289). The case for Hammurabi's enmity for his old comrade in arms includes the following conjunction of additional evidence:

(i) Zimri-Lim's renewed friendship with Ešnunna, evidenced by a costly gift sent on 6.viii.ZL12' (ARM 2519 ; see table). Yet, it must not be forgotten that Șilli-Sin, ruling Ešnunna at the time, was married to Hammurabi's daughter. (Not as likely, the daughter was Hammurabi of Kurda's.) In fact, the same text also records the dispatch of a gift to Hammurabi, and although three contemporaneous kings (Yambad, Kurda, Babylon) bore that name, there is no reason to eliminate Hammurabi of Baby-
Yet, when one surveys the administrative archives of the last year, it is very difficult to find any evidence of a city in alarm during its last months (see table). On closer inspection, the sensational letter Durand quotes proves to be authored by someone whose knowledge of events in the Babylonian palace was, at best, third-hand. The passages alerting Mari of Babylonian hostility can all be assigned to earlier contexts (Sasson, forthcoming). ${ }^{17}$ In any case, they are so rare that Durand himself wonders whether after his victory Hammurabi kept such letters to build cases against those who sided with Mari (Durand 1988a: 401). ${ }^{18}$ Charpin, however, proposes that ZimriLim may either have lived elsewhere than at the palace during his last days or may not have had a chance to store the warnings he had received on his last trip from his capital (Charpin 1995a: 39 and n. 39). ${ }^{19}$

lon from contention. Puzur-Šamaš, mentioned as in charge of the transaction recorded in ARM 2519 , left us a record of involvement with outlays to the king of Kurda as well as of Babylon. For more gifts from Ešnunna, see Ozan 1997: 296.

(ii) There was a rapprochement between Išme-Dagan, an old enemy of Zimri-Lim, and Hammurabi; see Charpin 1988: 156, with reference to ARM 26104 , “ . . . il n'est pas du tout exclu que le revirement d'attitude d'Hammu-rabi à l'égard de ZimriLim qui conduisait à la chute de Mari ait été, en partie au moins, l'œuvre d'Išme-Dagan." Yet, Išme-Dagan, for a brief period, was Zimri-Lim's vassal.

(iii) $A R M 26155$ and 185b (= ARM $10134+177$ ) are texts about omen-taking regarding Babylon's intentions. The former cannot be dated with certainty. The latter, however, because it implies the demise of Atamrum of Andarig, is probably postZL11'. Atamrum's fall led to a strong move on the part of Hammurabi to spread his influence toward the Habur region, possibly making Mari nervous. Yet, omens were commonly taken whenever troops moved in and out of a city's orbit and questioning their intentions was part of the routine, not necessarily reflecting alarm.

${ }^{17}$ It may be possible that Hammurabi had a large contingent of troops in the Idamaras just as the archives peter out (Abrahami 1992: 163). But it is not clear that the troops were threatening Mari. Other letters that describe tension between Babylon and Mari before Zimri-Lim's final year are ARM 26 40 (written by Asqudum, who likely died before ZL8'), 102 and 155 .

${ }^{18}$ In his fine overview of the Mari archives for the $A B D$ (1991: 533) Durand speculates that Zimri-Lim himself destroyed potentially incriminating correspondence.

19 But note his remark in Charpin 1996: 187: "Il est très vraisemblable qu'Išbi-Erra les [the Ur III archives] ait déménagés lorsqu'il prit la ville, comme le fit Hammu-rabi avec une partie de la chancellerie de Zimri-Lim à Mari." 
In fact, Zimri-Lim's last year had started well, with the arrival of much booty from the conquest of a rebellious city (see table, sub 13.i). The king had been in the north and, on his way back at mid-year, even had Siptu meet him in one of his Habur palaces (see 8.v). He was likely in Terqa by 17.v, spending a few days there before getting home by the 26th of the same month. No doubt he had the occasion to greet Sumu-ditana, one of two sons Hammurabi had sent to Zimri-Lim a year earlier, and this particular prince may well have continued to dwell in Terqa at that time (Lion 1994). An intriguing document from 20.vi (ARM 23 422) records a gift offered to woman breastfeeding a Babylonian infant girl, possibly Hammurabi's grandchild (see also at 22.viii).

In the final months, everything seemed normal, with the king's table being particularly rich during month vi (igi.kur). Foreign kings were coming to pay homage, vassals were sending gifts, sheikhs were delivering sheep, magnates were conveying wine, administrators were transferring grain, and artisans were withdrawing precious metal to complete their assignment. The last dated text is from 4.xii; but there is also a later document, dated to 21.xii, from a parallel year. I cannot even confirm that the king was away from the palace when death, in my opinion probably natural, arrived. So I speculate on what could have happened.

Zimri-Lim left a young son, perhaps two, neither of whom was ready for rule and, as was done in similar circumstances, Hammurabi was called on either to protect the city or to impose a new ruler on it. We do not know why he chose to do neither. Perhaps another game of geo-politics was being played; perhaps Mari was too distant to keep under firm control; perhaps (and this must be admitted), Hammurabi had always wanted to neutralize a powerful kingdom to his north and the opportunity was now there to do it bloodlessly. But he certainly did come. The first half of the Babylonian's thirty-third yeardate formula says plainly enough that Hammurabi "overthrew the armies of Mari and Malgium in battle" (after Stol 1976: 38). Yet, we know that Babylonian scribes were in Mari already a few months earlier (ThureauDangin 1939). While there, these scribes took inventory of the archives, sorting and, within a few days, packing into containers an enormous number of tablets belonging to Zimri-Lim and to his predecessor. I am not the first to doubt that they could have carried out this laborious task without help of resident scribes (Finet 1986: 153).

That thirty-third year-date formula of Hammurabi, however, has more to say. It continues by relating how "Mari and its villages and the many towns of Subartu submitted peacefully to (Hammurabi's) authority" (after Stol 1976: 38). In other allusions to Mari (including one in his famous law collection) Hammurabi seemed proud of having moved its population elsewhere to safety, and I think that such notices corroborate a peaceful transfer of power. ${ }^{20}$ In fact, no human remains were found in the palace; and since, beyond the tags left by Hammurabi's archivists, we have no administrative texts dated either to Hammurabi, or to anyone else who might have succeeded Zimri-Lim, we need to consider that the move out of Mari must have occurred soon after the arrival of the Babylonians. At any rate, it took Hammurabi two years to work out Mari's fate and to empty its treasuries. Saying that he was obeying the orders of his god, Anu, Hammurabi had the city put to the torch. The Babylonians in charge of carrying out the orders apparently found no use for the tablets so painstakingly assembled by their sribes; and they left them all behind. They are all there now and we can reassemble them, as their inner evidence and our own sense of the past dictate. ${ }^{21}$

\footnotetext{
${ }^{20}$ But note Durand 1995: 350-51, “Se sabe, por otra parte, que Mari cayó con relativa facilidad y que Hammu-rabi pretendió incluso que se le acogiese amigablemente en el Reino de Orillas del Éufrates. Ciertos súbditos de Mari pudieron preferir traicionar a un rey perjuro antes que ser sus cómplices implicítos, ayudándole en la guerra."

21 Although we have no information about the fate of ZimriLim or of any of his immediate kin, that his name was assumed by a ruler in the same region a couple of generations later may indicate that he did not die in disgrace (Rouault 1992: 251-52; for chronology, see Charpin 1995b). I even keep an illusion that the Yabdun-Lim who ministered to Hammurabi of Yambad a generation after the fall of Mari may well have been one of Zimri-Lim's sons, for in the Leilan archives there is one document (LT 87-653) where a Yabdullim receives precious vessels of more value than those sent to Prince Abbā [= Alalah's Abban] and to Kilimani, eventually King Abban's minister (Vincente 1991: 142-43 [no. 53], 189-90). If so, the boy may have been taken to Aleppo, where his father (Zimri-Lim) and grandfather (Yabdun-Lim) had found their queens (Durand
} 1990c: 291).

Moreover, Zimri-Lim may have been recalled beyond Mari by latter scribes. Following H. Güterbock (1978: 219), A. Archi (1995: 2370) refers to a fragmentary Hittite composition that possibly "describes Anum-Khirpi, the eighteenth-century king of Mamma, as a foundling who grew up at the court of ZimriLim. Notable characters reflect the relationships that bound eastern Anatolia and Mari during this period." (If so, this Anumbirpi is likely to be Anu/Aniš-hirwi of Zalwar; see Guichard 1993.) The passage in question, apparently occurring in KBo 12.3, is not well preserved and, according to G. Beckman (private communication), has had a number of readings, none 
As I end, I imagine you have noticed that I too did not resist filling gaps at either side of Zimri-Lim's life. My excuse is that I am not normally a political historian and therefore do not plot continuity and change, arrest and movement across appreciable stretches of space and time. Yet, for me biography is not just a vehicle for promoting edifying lives or a design for revealing the universal through the particular. Rather, the genre gives also fine opportunity to exhibit a culture, one generation at a time, at a specific moment of the past. In this sense, my account of the search for a beginning and an end to Zimri-Lim's life neither unmasks the failure of our documentary evidence nor exposes our capacity for fanciful reconstructions. I hope, instead, to have offered you a paradigm to test. I am proposing that we are likely to give completion to the lives of figures from antiquity, at least those about whom we care, whether or not there is a dearth or a surfeit of evidence. But the shape these lives will take might depend as much on our perception of the past as on the values we currently hold about human interactions. ${ }^{22}$

As for Zimri-Lim, I am not sure how he will fare a few years from now. But I remain hopeful that as we continue to dot the historical canvas, it will be possible to pull back a few feet and admire the likeness, not of another page from a historical atlas, but of an oriental Grande Jatte, a Mari kārum where, among the many strollers he had helped to resurrect, will be Zimri-Lim, posed slightly less bemused, no longer as uncertain how he got there or where to head for a graceful exit.

\section{APPENDIX}

KINSHIP TERMINOLOGY AND POLITICAL METAPHORS IN TWO MARI LETTERS (A.1101 AND A.1153)

In Old Babylonian diplomatic circles, kinship terminology was commonly used as metaphor for political allegiance. Zimri-Lim could call himself the "son" of Yarim-Lim of Aleppo; but upon the latter's death, the new king of Aleppo, Hammurabi, initially calls himself the "son" of Zimri-Lim. This is a gesture that a new king readily assumed, whether or not his correspondent was older. By the time the archives peter out, Hammurabi can call Zimri-Lim "brother." Something similar occurs in the case of Yatar-Ami who, upon becoming king of Karkemish, is quoted as telling Zimri-Lim (ARM 26 537): "My father Aplahanda has not died; he still lives. ZimriLim is my father and Yatar-Ami is truly your son. Hold him in your hand and in order for him not to feel that his father has indeed died, speak candidly with him."

During wartime, a combatant in need of troops could write to his "father"; but in all other times, they are "brothers." This notion is made clear by a letter to ZimriLim (FM 2 117, Lafont 1994) sent by a group of political advisors:

When we arrived to Mari with our lord ..., about Simah-ilane we made the following declaration before our lord: "Our lord should make an effort to bring out Simab-ilane from where he is now, so that our lord could restore the $\mathrm{Sim}^{\text {}} \mathrm{al}$ and Numaha (tribes) to a single finger that cannot be split. Until our lord brings out Simahilane, he should correspond with Hammurabi as a 'son'

conclusive. P. Michalowski informs me (also privately) of another fragmentary passage in an unpublished text that seems to mention Zimri-Lim, Hammurabi, and the city of Ešnunna. (marūtam ana Hammurabi lišpur)."

My lord has listened to the appeal of his servants; he has corresponded with Hammurabi as a "son," and he indeed did bring out Simah-ilane. But when my lord corresponded with Hammurabi (again), he did not do so as a "son." My lord should keep this in mind.

This shift in terminology and its implication must have been crystal clear to the people of the time; but it could be confusing to us, leading us to reconstruct false relationships, whether we take the vocabulary to be about kinship or power. In fact, the circumstances under which one was permitted to call another "brother" rather than "father" were controlled by an elaborate protocol, with harsh retaliation for infraction, as demonstrated by the wonderful letters Lafont published recently (1994). In them, the elders of Kurda are blamed (I think as scapegoats) for forcing a king to address Zimri-Lim as a "brother" rather than as a "son." Lafont (forthcoming) has recently studied this convention. It might be added that it seems equally applicable to the world of elite women, when someone like Tariš-hattum, a Terqa matron, could call Siptu "daughter" (ARM 10 114: 22-25).

The dossier in which Zimri-Lim begs Yarim-Lim for help includes two letters (Dossin 1973), written to coax release of grain from Emar. One letter is from Sammetar, instructing the king on how to plead his case (A.1101, Dossin 1973: 184-88; Durand 1997: 362-64 [no. 230], with crucial collations). The other is from Zimri-Lim himself, in which he declares himself loath to rely on Hammurabi (A.1153, Dossin 1973: 180-84; Durand 1987b:

\footnotetext{
${ }^{22}$ I have been enriched by reading the five essays edited in Kramer 1991 and Oats 1986. In particular, I have profited from reading Tuchman's essay (Tuchman 1986).
} 
669-70, collations with fine tuning by Veenhof 1992). The two texts could be related, however, only if Hammarubi of Babylon is involved. Yet, the mention of shipping grain by donkey rather than by boat may suggest that Hammurabi of Kurda is at issue in A.1153. If so, the two texts cannot be related because Sammetar died in early ZL6' while Hammurabi did not take over at Kurda until mid-ZL6' (earliest archival attestation is 16.xii.ZL6 ${ }^{\prime}$ [ARM 21 94]). The dossier would therefore refer to two entirely different events, albeit both of its letters concern Mari's endemic harvest problems. Durand (1997: 363) may well be right in setting Sammetar's letter around ZL5', a period that followed two years of war against the Benjamin tribes. As to A.1153, most likely it should be connected with the bad harvest yeas of $Z L 7^{\prime}-8^{\prime}$, when Mari was forced to import grain (see, most recently, Michel 1996: 391-94). At this time, too, Zimri-Lim was sending Yarim-Lim much tin.

In considering the two letters, it is useful to examine how Sammetar advances diverse excuses for Zimri-Lim to use. Earlier he had proposed that the shortage of grain be blamed not on war but on flooding or some other natural calamity. Now he would have war be the major culprit.

Previously, I had offered the king the following advice on contacting Yarim-Lim about grain supplies. (Seasonal) flooding could have carried away the harvest of my lord's grain. Or, it could have been ruined by bad weather, therefore my lord could not achieve it. It is not because of hostility that he [i.e., Zimri-Lim] could not reap the grain of my lord's land as a full harvest, and consequently my lord has been embarrassed to write.

This is the advice I previously offered by lord. Apparently they have not reminded my lord, and my lord has not (yet) written Yarim-Lim about this matter. My lord should now reconsider, and write Yarim-Lim the following: "During hostilities, I have not reaped a full harvest of my land's grain for two full years now, with grain becoming scarce in my land."

My lord should certainly write in this way but not the other. Should it happen that sooner or later Yarim-Lim takes up the matter with my lord, saying, "the harvested grain becoming so scarce in your land, why did you not send me a message?" My lord could then have a grievance against him. (A.1101)

It is impossible to know how true were the three potential excuses that Sammetar was advancing, and we should be careful not to create historical settings for them automatically, even though grain shortages troubled Mari often enough. At any rate, whether or not the two letters are linked historically, it will be evident that, when Zimri-
Lim does write Yarim-Lim (A.1153), he adopts war as an excuse, but he weaves around it fairly sophisticated layers of argument and tactics that aim to mollify his father-in-law. Still, the fact that this letter remained in the Mari archives may indicate that it (or this particular draft of it) was never sent. I comment on each of its segments. Zimri-Lim begins by saying:

I hear the following said: "In Emar, there is much grain belonging to the merchants; as to conveying the barley to Mari, Yarim-Lim is opposed." This is what I have heard.

What is this? Why is my lord finding pleasure in my not being strong? Does it suit what has been said to me: "As to Zimri-Lim, I myself have set him on his throne. I want to do what strengthens him and what secures the foundation of his throne"? But you oppose the conveying of grain to Mari. (A.1153: 3-12)

In addressing Yarim-Lim, Zimri-Lim begins by indicting actions taken in Emar. But in fixing the blame on Yarim-Lim, he is also careful not to give the accusation specific credit. He then quotes Yarim-Lim's pledge to affirm Zimri-Lim, though he does not confront him with it. How true this statement is is difficult to say. We know that others took credit for Zimri-Lim's rise to power, such as Addu of Halab (Sasson 1994: 314-16) and Ibalpi-El of Ešnunna. During their negotiations over a peace treaty, Ibalpi-El actually sent a throne to ZimriLim, concretizing the metaphor for installation (Charpin 1991: 156, 158 n. 39; Durand 1997: 436-37 [no. 381]). The vocabulary used is worth repeating (1l. iii: 28-37): "... Now I am conveying to you a great [...] throne, symbol of kingship; sit on it, so that those kings who surround you could see and realize how Ešnunna is indeed your great ally. Just as your father Yahdun-Lim, on grasping the hem of the House of Ešnunna, became powerful and enlarged his land, because you are my son and plan to continue grasping my hem-I myself shall be forthright with you, will broaden your perimeters, will restore the city Mari to its former size, and will affirm your foundation. ..."

At the same time, Hammurabi sent me the following letter. "If grain at your disposal is scarce, write me and I can load up 50,000 donkey (measures) and convey it by a caravaneer [Veenhof 1992, "at the earliest opportunity"] to Mari." But I, because I have relied on you, answered him saying: "Don't transport any grain to me; there is much of it here. It is among you that it is lacking." This answer did I give Hammurabi. (A.1153: 13-23a) 
In this segment, Zimri-Lim tries to shame Yarim-Lim into action by suggesting that another power could fulfill Mari's request. If, as I have speculated above, this Hammurabi is the king of Kurda, the humiliation would be more complete, in that a much less significant power (indeed a vassal of a vassal) might offer sorely needed help. Zimri-Lim averts humiliation by couching the exchange between him and Hammurabi as a contest of will (a known Mesopotamian literary genre), where terms are hyperbolically stated ("fifty thousand" units, at eighty liters each), and impudence given its just rebuke.

However, in my heart I had the following thought: "It is my father, who brought me to my throne, who will strengthen me and will secure the foundation of my throne." Now, ever since I came to the throne many days ago, I have been to wars and battles, and have never ever brought in a full harvest. If in truth (you are) my father, make it your business to strengthen me and to secure the foundation of my throne. My father should pay attention to what is in this letter of mine. The merchants controlling the grain which is in Emar should send the boats on their way, and thus bring calm to the land. (A.1153: 23b-36)
In this segment of the letter, what Zimri-Lim initially attributed to Yarim-Lim ("As to Zimri-Lim, I myself have set him on his throne. I want to do what strengthens him and what secures the foundation of his throne"), turns out to be Zimri-Lim's own sentiment, delivered as if from his innermost being. Any specific advice remembered from Sammetar about how to formulate his excuse is made vague as Zimri-Lim generalizes on the duration of hostility that kept him from realizing a full harvest. The third rehearsal of Yarim-Lim's alledged statement is now couched as a demand: Yarim-Lim cannot claim Mari's allegiance without agreeing to sustain Zimri-Lim! Harking back to the opening lines of the letter, but without explicitly invoking Yarim-Lim's authority over Emar, Zimri-Lim demands the release of the grain from Emar.

The letter could have ended here. But Zimri-Lim adds a few more words to remind Yarim-Lim that Halab still needs Mari's good offices to obtain needed tinbut also to muffle the mood of crisis his letter may be communicating:

I have now conveyed (all) the tin at my disposal. When (more) reaches me, however, I will convey it to you. Letters with news of the well-being of my lord should come to me regularly. (A.1153: 37-41)

TABLE: Year ZL12'

"Year: Zimri-Lim a second time captured Ašlakka"a

\footnotetext{
Z11'b

ZL9

Unknown dates

M.10383

M.11555

M.8890

M.15184

ARM 24207

ARM 25744

ARM 25775

M.5834

M.10319-23

ARM 23588

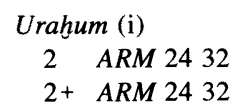

\author{
= "Year following: Zimri-Lim presented a great throne to Dagan in Terqa" \\ = "Year: Zimri-Lim vanquished Eluhtum"b
}

\author{
(ARM 26/1, 399) mention of Šelebum (assinum ${ }^{\text {) }}$ ) among other VIPs \\ (ARM 26/2, 41 n. 90) mention of Šadum-labu ${ }^{\supset}$ a of Ašnakkum (see below sub 19.xi) \\ (ARM 26/2, 41 n. 90) mention of Šadum-labu'a of Ašnakkum (see below sub 19.xi) \\ (Durand 1988b) individual given to Yahdullim (king of Karkamiš) (see below, sub 4.ix) \\ inventory of tin, garments \\ metal received in Saggaratum \\ fragment \\ (Durand 1985: 402); text mentions palace lady, Bēltum (the queen?; see below under 5.v, ?.ix, 1.ix) \\ ZL9 (Durand 1987a: 99 n. 185); wine outlay registered in M.10318 (22.v.) to M.10324 (13.vii), below \\ inventory of grain outlay over 13 months (v.ZL11' to vi.ZL12'), including rations and drinks for \\ princesses Tariš-mātum and Napsinu and 4 months of rations to men from Elubtum ${ }^{c}$
}

animals from Haya-Sumu (king of Ilanșura)

10 suqãqus bring in sheep

a Some unpublished texts are cited repeatedly in the literature. I give here reference to their earliest or fullest mention.

b The equation ZL12' = ZL9 was first offered by Materne 1983: $195 \mathrm{n}$. 1. It has been repeated by a number of scholars, among them Anbar (1987: 642) and Durand (1986: 127), who earlier (ARMT 21, pp. 158-59 n. 18) had suggested that it may have been ZL13'. The equation, however, is not beyond doubt.

c The two princesses are likely daughters of Yahdun-Lim, see Durand 1985: 393.
} 


\begin{tabular}{|c|c|}
\hline 18 & ARM 24206 \\
\hline 22 & M.10318 \\
\hline 26 & M.10319 \\
\hline 26 & $A R M_{\mathrm{x}} 465$ \\
\hline \multicolumn{2}{|c|}{$I G I . K U R(\mathrm{vi})$} \\
\hline$?$ & $A R M 874$ \\
\hline$?$ & ARM 21203 \\
\hline 2 & ARM 913 \\
\hline 3 & M.10324 \\
\hline 9 & $A R M 2199$ \\
\hline 12 & $A R M 2165$ \\
\hline 17 & ARM 2166 \\
\hline 18 & ARM 2166 \\
\hline 19 & M.15077 \\
\hline 19 & M.15109 \\
\hline 20 & $A R M 23422$ \\
\hline 23 & ARM 2167 \\
\hline 27 & $A R M 21101$ \\
\hline 30 & $A R M 25120$ \\
\hline \multicolumn{2}{|c|}{ Kinūnum (vii) } \\
\hline 3 & ARM 25441 \\
\hline 4 & ARM 21126 \\
\hline 13 & M.103xx \\
\hline 15 & ARM 25120 \\
\hline 15 & ARM 25443 \\
\hline 17 & ARM 25442 \\
\hline 23 & ARM 25427 \\
\hline & ARM 24137 \\
\hline \multicolumn{2}{|c|}{ Dagan (viii) } \\
\hline 5 & A. 3947 \\
\hline 6 & $A R M 2519$ \\
\hline 22 & ARMT 23, 74 \\
\hline 25 & ARM 24205 \\
\hline 29 & $?$ \\
\hline 30 & $A R M 23608$ \\
\hline \multicolumn{2}{|c|}{ Liliatum (ix) } \\
\hline$?$ & M.11381 \\
\hline$?$ & ARM 21349 \\
\hline 1 & ARM 2491 \\
\hline 1 & $A R M 21102$ \\
\hline 4 & ARM 23222 \\
\hline 6 & ARM 23222 \\
\hline
\end{tabular}

reception of garments

ZL9 (Durand 1987a: 99); outlay of wine. For other texts in series, see sub M.10319-10323 (above)

ZL9 (Villard 1992: 199 n. 36); outlay of wine, "when the king reached Mari, after completing his trip"; 10 jars brought by a man from Ursum (see $A R M T 23,429$ )

ZL9? (see Villard 1992: 199 n. 35); naptan šarrim (king's meal) in Marig

loan to be repaid in iv.ZL13'

silver from 4 VIPs, ana kulili?, received by Mukannišum, in Mari; see sub 1.vi

(here?) memo that 144 wine jars from the custom were collected. Month is Terqa's Birizarrum

ZL9 (See Durand 1987a: 92, 99 n. 185; FM 3, p. 47); wine, "on entering Annunitum (into the palace)"

212 jars of wine, brought from the vineyards of 4 men in Hišamta

meat portions, for the king's meal [year not stated]

meat portions, in care of 2 male cooks

meat portions, in care of same 2 cooks

(Catagnoti 1992: 25) sheep, when the queen (Šiptu) made a sappum sacrifice to Ištar of Tuba, in the sakannum; stocking fattened sheep, entrusted to Addu-rabi

(Catagnoti 1992: 26) ditto; entrusted to Subnalu

object made for a wetnurse (mušēniqtum) of a Babylonian girl (see below, sub 22.viii)

meat portions, received by 3 male cooks

a kanakurtum-vessel, when blending (wine) for the king

material given to (for?) Yahdullim, king of Karkemiš, in Terqa (see 15.vii below and $N A B U$ 88/2)

gold received by Binma-ahim and Ili-ištikal, to make vases

ZL9; oil outlay ${ }^{\mathrm{h}}$

ZL9 (Durand 1987a: 99 n. 185); wine outlay, some from Ursum (ARMT 23, p. 429), "on entering Annunitum (into the palace)" (Durand 1987a: 92)

(M.7328) material received in Mari . . 1 weapon for Ahi-malik, 2 vases made of one shekel of gold for Hammu-laba. This is the final entry for a sequence that began on 10.v. (see $N A B U 88 / 2$ )

precious material, to manufacture decorations, assigned to Subnalu

ZL9 (see Durand 1987a: 126); memorandum on material for making jewelry, assigned to Šubnalu ${ }^{\mathrm{i}}$ silver received by Zilatum

amount of silver lost in melting stars on two coffers

(Charpin 1985: 56 n. 41) mentions gifts sent to Șilli-Sîn, king of Ešnunna

2 gold kirru vases, one to Șilli-Sîn, king of Ešnunna, one to Hammurabi (of ?); from the reserve of

Puzur-Šamaš in Terqa (A.3493; date collated by Durand 1992a: 47 n. 48) j $^{\mathrm{j}}$

Tabura, a mušenniqtum is referred to as a ummum (see above, sub 24.iv)

garments given out to people upon bringing objects to Bahdi-Lim's house(?)

ZL9 (Birot 1960: 267); outlay of oil

ZL9; garments outlay to domestics

(Durand 1988) clothing for Yahdullim, king of Karkamiš; see M.15184, above diverse garments and textiles, from the weavers of B/bēltum (the queen?) inventory of silver vessels

honey, entrusted to B/bēltum (the queen?), for work of housekeepers (abarakkātum)

40 sheep presented at Mari by officials and governors [see above sub 30.iv]

17 sheep presented by Haya-Sumu (king of Ilanșura?) by Addu-rabi in Mari

g M.11627 (=ARM 25: 104) should date to ZL2' or 3'; see Guichard 1994: $268 \mathrm{n} .108$.

${ }^{\mathrm{h}}$ Durand dates this text to ZL2'. But Ablamu, mentioned in this document, is not involved in oil transactions before ZL5', see Sasson 1987: 583 n. 12.

' Worth noting the conjunction of records, one from ZL12' the other from ZL9. See also sub 6.v.ZL12' and 2.vi.ZL9.

j See above, n. 16. 


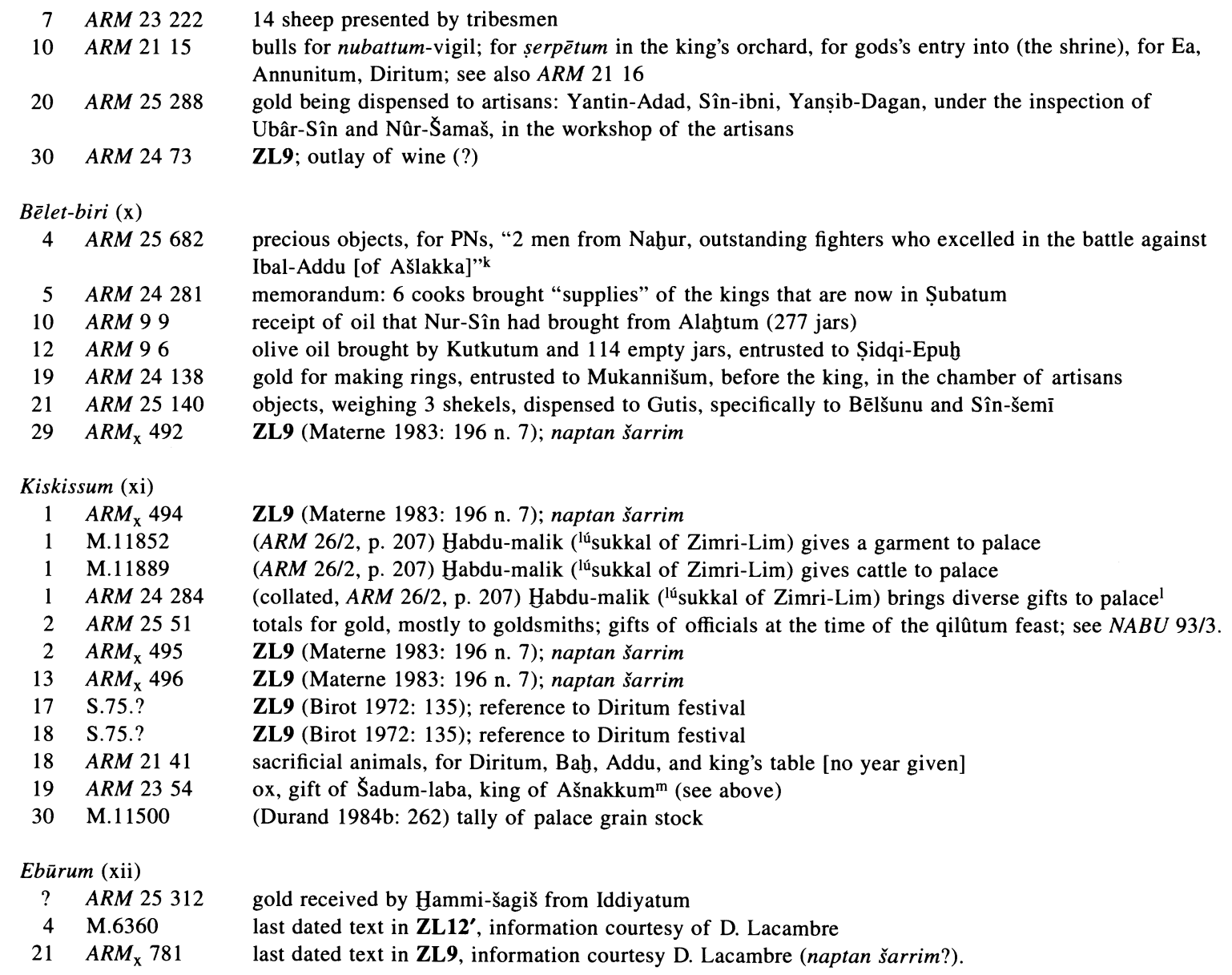

\footnotetext{
k See ARM 2 141: 11-14, “. . during the victory over Idamaraz, with 10 other outstanding men, these men excelled." See also Durand 1988a: 54 n. 257.

${ }^{1}$ A year earlier, Habdu-malik had tried, but apparently failed, to bring peace between Atamrum of Andarig and Hammurabi of Kurda.

${ }^{\mathrm{m}}$ M.11555 (ARM 26/2, 41 n. 90), may belong here. It mentions Šadum-laba as the king of Ašnakkum.
}

\section{BIBLIOGRAPHY}

Abrahami, P. 1992. La circulation militaire dans les textes de Mari: La question des effectifs. In La Circulation des biens, des personnes et des idées dans le Proche-Orient ancien, ed. D. Charpin and F. Joannès. Pp. 157-66. Actes de la XXXVIII ${ }^{\mathrm{e}}$ Rencontre assyriologique internationale, Paris, 8-10 juillet 1991. Paris: Éditions Recherche sur les Civilisations.

Albright, W. F. 1968. Yahweh and the Gods of Canaan: A Historical Analysis of Two Contrasting Faiths. The Jordan Lectures, 1965. Garden City, N.Y.: Doubleday.
Anbar, M. 1979. La durée du règne de Zimri-Lim, roi de Mari. IOS 9: 1-8.

1987. Review of J.-M. Durand, ARM 21; of J.-R. Kupper, ARM 22; and G. Bardet et al., ARM 23. MARI 5: 640-42.

Archi, A. 1995, Hittite and Hurrian Literature: An Overview. In Civilizations of the Ancient Near East, ed. J. M. Sasson et al. Pp. 2367-77. New York: Scribners.

Birot, M. 1960. Textes administratifs de la salle 5 du palais. Archives royales de Mari, transcrits, traduits et commentés, 9. Paris: Imprimerie nationale. 
1972. Simablânê, roi du Kurda. Revue d'assyriologie 66: $131-39$.

1978. Données nouvelles sur la chronologie du règne de Zimri-Lim, Syria 55: 333-43.

Catagnoti, A. 1992. Le royaume de Tubâ et ses cultes. In Florilegium marianum: Recueil d'études en l'honneur de Michel Fleury, ed. J.-M. Durand. Pp. 23-28. Mémoires de N.A.B.U. 1. Paris: SEPOA.

Charpin, D. 1985. Données nouvelles sur la chronologie des souverains d'Ešnunna. In Miscellania Babylonia: Mélanges offerts à Maurice Birot, ed. J.-M. Durand J.-R. Kupper. Pp. 51-66. Paris: Éditions Recherches sur les Civilisations.

1988. Les représentants de Mari à Babylone. In Archives épistolaires de Mari, I/2, ed. D. Charpin et al. Pp. 139-205. Archives royales de Mari, XXVI. Paris: Éditions Recherches sur les Civilizations.

1990. A Contribution to the Geography and History of the Kingdom of Kahat. In Tall al-Hamidiya, 2: Symposion: Recent Excavations in the Upper Khabur Region, Berne, December 9-11, 1986, ed. S. Eichler et al. Pp. 67-85. Orbis Biblicus et Orientalis, Series Archaeologia, 6. Freiburg: Universitätsverlag.

1991. Un traité entre Zimri-Lim de Mari et Ibâl-pîEl II d'Ešnunna. In Marchands, diplomates et empereurs: Études sur la civilisation mésopotamienne offertes à Paul Garelli, ed. D. Charpin and F. Joannès. Pp. 139-66. Paris: Éditions Recherche sur les Civilisations.

1992a. Les légendes de sceaux de Mari: Nouvelles données. In Mari in Retrospect: Fifty Years of Mari and Mari Studies, ed. G. D. Young. Pp. 59-76. Winona Lake, Ind.: Eisenbrauns. [Note: this essay for a 1983 symposium was updated only through 1986.]

1992b. Mari entre l'Est et l'Ouest: Politique, culture, religion. Akkadica 76: 1-10.

1994. Une campagne de Yahdun-Lîm en Haute-

Mésopotamie. In Charpin and Durand 1994. Pp. 177-200.

. 1995a. La fin des archives dans le palais de Mari.

Revue d'assyriologie 89: 29-40.

1995b. À propos des rois de Hana. NABU 1995: 19-

20 (no. 23).

. Review of G. Jonker, The Topography of Remem-

brance (Leiden: E. J. Brill, 1995), in Revue d'assyriologie 90: 186-90.

Charpin, D., and J.-M. Durand. 1985. La prise du pouvoir par Zimri-Lim. MARI 4: 293-343.

1991. La suzeraineté de l'empereur (sukkalmab) d'Elam sur la Mésopotamie et le "nationalisme" Amorrite. In Mésopotamie et Elam, ed. L. de Meyer and H. Gasche. Pp. 59-66. Mesopotamian History and Environment, Occasional Publications, I. Actes de la XXXVI ème Rencontre assyriologique internationale, Gand, 10-14 juillet 1989. Ghent: Ghent University Press. ,ed. 1994. Florilegium marianum, 2: Recueil d'études à la mémoire de Maurice Birot. Mémoires de N.A.B.U., 3. Paris: SEPOA.

Charpin, D., and N. Ziegler. 1997. Mekum, roi d'Apišal. MARI 8: 253-47.

Dossin, G. 1937, La correspondance de Zimrilim, dernier roi de Mari. Comptes-rendus des séances d l'Académie des inscriptions et belles-lettres, année 1937. Pp. 12-20.

1938. Les archives épistolaires du palais de Mari, Syria 19: 105-26 (= Dossin 1983: 102-32).

1939. Les archives économiques du Palais de Mari.

Syria 20: 97-113 (= Dossin 1983: 133-49).

1949. Sibtu, reine de Mari. In Actes du XXI ${ }^{e}$ Congrès

des Orientalistes. Pp. 142-43. Paris: Imprimerie nationale. 1950. Les noms d'années et d'éponymes dans les

"Archives de Mari." Studia Mariana, ed. A. Parrot. Pp. 5161. Documenta et Monumenta Orientis Antiqui, 4. Leiden: E. J. Brill.

1952. Le royaume d'Alep au XVIII' siècle avant notre ère d'après les "Archives de Mari." Bulletin, Académie royale de Belgique 38: 229-39 (= Dossin 1983: 300-310). 1967. Correspondance féminine. Archives royales de Mari, 10 (= Textes cunéiformes du Louvre, 31). Paris: Geuthner.

1973. Une opposition familiale. In La Voix de l'opposition en Mésopotamie, ed. A. Finet. Pp. 179-88. Brussels: Institut des Hautes Études de Belgique.

1983. Recueil Georges Dossin: Mélanges d'assyriologie (1934-1959), ed. A. Finet. Louvain: Peters.

Dossin, G., and A. Finet. 1978. Correspondance féminine, transcrite et traduite par Georges Dossin. Archives royales de Mari, 10. Paris: Geuthner.

Durand, J.-M. 1984a. Trois études sur Mari. MARI 3: 127-79. 1984b. Sur un emploi du verbe bullutum. MARI 3: 260-64.

1985. Les dames du palais de Mari. MARI 4: $385-$ 436.

1986. Fragments rejoints pour une histoire élamite. In Fragmenta historiae aelamicae: Mélanges offerts à M.-J. Steve, ed. L. De Meyer et al. Pp. 111-28. Paris: Editions Recherche sur les Civilisations.

1987a. L'Organisation de l'espace dans le palais de Mari: Le Témoignage des textes. In Le Système palatial en Orient, en Grèce et à Rome: Actes du Colloque de Strasbourg, 19-22 juin 1985, ed. E. Lévy. Pp. 39-110. Travaux du Centre de recherche sur le Proche-Orient et la Grèce antiques, 9. Leiden. E. J. Brill.

1987b. *Bakîram = «auparavant». MARI 5: 667-70.

1988a. Archives épistolaires de Mari, I/1. Archives royales de Mari, 26. Paris: Éditions Recherche sur les Civilisations.

1988b. Rois de Syrie du nord. NABU 1988: 2-3 (no. 2). 
1988c. Les anciens de Talhayûm. Revue d'assyriologie 82: 97-113.

1990a. La Cité-État d'Imar à l'époque des rois de Mari. MARI 6: 39-92.

1990b. Fourmis blanches et fourmis noires. In Contribution à l'histoire de l'Iran: Mélanges offertes à Jean Perrot, ed. F. Vallat. Pp. 101-8. Paris: Édition Recherches sur les Civilisations.

1990c. Documents pour l'histoire du royaume de Haute-Mésopotamie, II. MARI 6: 271-301.

1991. Mari: Texts. Anchor Bible Dictionary 4: 529-38.

1992a. Espionnage et guerre froide: La Fin de Mari. In Florilegium marianum: Recueil d'études en l'honneur de Michel Fleury, ed. J.-M. Durand. Pp. 39-52. Mémoires de N.A.B.U. 1. Paris: SEPOA.

1992b. Unité et diversités au Proche-Orient à l'époque

amorrite. In La circulation des biens, des personnes et des idées dans le Proche-Orient ancien, ed. D. Charpin and F. Joannès. Pp. 97-128. Actes de la XXXVIII' Rencontre assyriologique internationale, Paris, $8-10$ juillet 1991. Paris: Éditions Recherches sur les Civilisations.

1993. Le combat entre le Dieu de l'Orage et la Mer. MARI 7: 41-70.

1994. Administrateurs de Qaț̣unân. In Charpin and

Durand 1994. Pp. 83-114.

1995. La Religion en Siria durante la Época de los

Reinos Amorreos según la Documentación de Mari. In Mitología y Religión del Oriente Antiguo, II.1: Semitas Occidentales (Ebla, Mari), ed. P. Mander and J.-M. Durand. Pp. 127-533. Collección Estudio Orientales, 8. Sabadell, Spain: Editorial AUSA.

1997. Documents épistolaires du palais de Mari, 1 . Littératures anciennes du Proche-Orient. Paris: Les Éditions du Cerf.

[Forthcoming.] Peuplement et sociétés au procheorient à l'époque amorrite. In Mari, Ebla, et les Hourrites: Dix ans de travaux (= Amurru 2). Paris: Éditions Recherche sur les Civilisations.

Eidem, J. 1991. The Tell Leilan Archives 1987. Revue d'assyriologie 85: 109-35.

Finet, A. 1973. La Voix de l'opposition en Mésopotamie. Bruxelles: Institut des Hautes Études de Belgique.

1986. Typologie des lettres des Archives «Royales» de Mari. In Cuneiform Archives and Library: Papers Read at the $30^{e}$ Rencontre Assyriologique Internationale, ed. K. R. Veenhof. Pp. 153-59. Leiden: Dutch Near East Institute.

Frayne, D. R. 1990. Old Babylonian Period (2003-1595). The Royal Inscriptions of Mesopotamia. Early Periods, 4. Toronto: University of Toronto Press.

Greengus, S. 1966. Old Babylonian Marriage Ceremonies and Rites. JCS 20: 55-72.
Groneberg, B. 1994. Dam-burāşim, Prinzessin aus Qaţnā und ihr nübalum. In Charpin and Durand 1994. Pp. 133-36.

Guichard, M. 1993. La Conquête de Haššum par le roi de Zarwar. NABU 1993: 46-47 (no. 54).

. 1994. Au pays de la Dame de Nagar. In Charpin and Durand 1994. Pp. 235-72.

Heintz, J.-G., D. Bodi, and L. Millot. 1990. Bibliographie de Mari: Archéologie et textes [1933-1988]. Université des sciences humaines de Strasbourg. Travaux du Groupe de recherches et d'études sémitiques anciennes, 3 . Wiesbaden: Harrassowitz.

. 1992-96. Bibliographie de Mari: Supplément I-V. Akkadica 77: 1-37; 81: 1-22; 86: 23; 91: 1-22; 96: 1-19.

Güterbock, H. G. 1978. Hethitische Literatur. In Altorientalische Literaturen, ed. W. Röllig. Pp. 211-53. Neues Handbuch der Literaturwissenshaft. Wiesbaden: Athenaion.

Huffmon, H. 1965. Amorite Personal Names in the Mari Texts: A Structural and Lexical Study. Baltimore: Johns Hopkins University Press.

Joannès, F. 1991. Le Traité de vassalité d'Atamrum d'Andarig envers Zimri-Lim de Mari. In Marchands, diplomates et empereurs: Études sur la civilisation mésopotamienne offertes à Paul Garelli, ed. D. Charpin and F. Joannès. Pp. 167-77. Paris: Éditions Recherche sur les Civilisations.

Klengel, H. 1992. Syria, 3000 to 300 B.C. Berlin: Akademie Verlag.

Kramer, M., ed. 1991. Middle Eastern Lives: The Practice of Biography and Self-Narrative. Syracuse: Syracuse University Press.

Kuhrt, A. 1995. The Ancient Near East c. 3000-330 B.C. Routledge History of the Ancient World. London: Routledge.

Lafont, B. 1987. Les filles du roi de Mari. In La Femme dans le Proche-Orient antique, ed. J.-M. Durand. Pp. 113-21. Actes de la XXXIII ${ }^{\mathrm{e}}$ Recontre assyriologique internationale. Paris: Éditions Recherche sur les Civilisations. ERC. . 1994. L'Admonestation des anciens de Kurdâ à leur roi. In ed. Charpin and Durand 1994. Pp. 209-30.

. [Forthcoming]. Les Relations internationales, alliances et diplomatie au temps des rois de Mari. In Mari, Ebla, et les Hourrites: Dix ans de travaux. (= Amurru 2.) Paris: Éditions Recherche sur les Civilisations.

Lambert, W. 1991. Samsu-Iluna in Later Tradition. In De la Babylonie à la Syrie, en passant par Mari: Mélanges offerts à Monsieur J.-R. Kupper à l'occasion de son $70^{e}$ anniversaire, ed. Ö. Tunca. Pp. 27-34. Liège: Université de Liège.

Lewy, H. 1962. Mari. In The Interpreter's Dictionary of the Bible, ed. G. A. Buttrick et al. 3: 264-66. Nashville, Tenn. Abingdon Press.

1967. The Chronology of the Mari Texts. In La Civilisation de Mari, ed. J.-R. Kupper. Pp. 13-28. Actes de la $\mathrm{XV}^{\mathrm{e}}$ Rencontre assyriologique internationale, Liège, 4-8 
Juillet 1966; Bibliothèque de la Faculté de philosophie et lettres, 172. Paris: Les Belles Lettres.

Lion, B. 1994. Des princes de Babylone à Mari. In Charpin and Durand 1994. Pp. 221-34.

Margueron, J.-C. 1990. La Ruine du palais de Mari. MARI 6: 423-31.

Marello, P. 1994. Esclaves et reines. In Charpin and Durand 1994. Pp. 115-29.

Materne, J.-P. 1983. L'Année de Kahat dans la chronologie du règne de Zimri-Lim. MARI 2: 195-99.

Michel, C. 1996. Le Commerce dans les textes de Mari. In Mari, Ebla, et les Hourrites: Dix ans de travaux (= Amurru 1). Pp. 385-426. Paris: Éditions Recherche sur les Civilisations.

Oats, S. B., ed. 1986. Biography as High Adventure: Life-Writers Speak on Their Art. Amherst: The University of Massachusetts Press.

Ozan, G. 1997. Les lettres de Manatân. In Florilegium marianum, 3: Recueil d'études à la mémoire de Marie-Thérèse Barrelet, ed. D. Charpin and J.-M. Durand. Pp. 291-305. Mémoires de N.A.B.U., 4. Paris: SEPOA.

Pardee, D. 1984. Literary Sources for the History of Palestine and Syria. Biblical Archaeologist 47: 88-99.

Parrot, André. 1966. La Vie d'un chef d'état au $\mathrm{II}^{\mathrm{e}}$ millénaire. In Institut de France: Séance publique annuelle [Mardi 25 Octobre, 1966] 26. Paris: Firmin-Didot et Cie.

Roden, C. 1996. The Book of Jewish Food. New York: Knopf.

Rouault, O. 1992. Cultures locales et influences extérieures: Le cas de Terqa. Studi Micenei ed Egeo-Anatolici 30: 247-56.

Rowton, M. B. 1962. Chronology: Ancient Western Asia. In The Cambridge Ancient History, rev. ed., vol. 1, fasc. 6. Cambridge: The University Press.

Sasson, J. M. 1980. Dated Texts from Mari: A Tabulation. ARTANES, 4. Malibu, Cal.: Undena.

1984. Thoughts of Zimri-Lim. Biblical Archaeologist, 47: 110-20.

1987. "Year: Zimri-Lim Dedicated his Statue to the

God Addu of Halab": Locating a Year in the Reign of ZimriLim. MARI 5: 577-89.

1994. The Posting of Letters with Divine Messages.

In Charpin and Durand 1994. Pp. 299-316.
[ [Forthcoming]. On Reading the Diplomatic Letters in the Mari Archives. In Mari, Ebla, et les Hourrites: Dix ans de travaux (= Amurru 2). Paris: Éditions Recherche sur les Civilisations.

Smith, S. 1940. Alalakh and Chronologie. London: Luzac \& Company.

1957. Yarim-Lim of Yamhad. Rivista degli Studi Orientali $[=$ Scritti in onore di Giuseppe Furlani, pt. I] 32: 155-84.

Stol, M. 1976. Studies in Old Babylonian History. Leiden: Nederlands Historisch-Archaeologisch Instituut te Istanbul.

Thureau-Dangin, F. 1936. Textes de Mâri. Revue d'assyriologie 33: 169-79.

1937. Iasmah-Adad. Revue d'assyriologie 34: 135-39.

1939. Sur des étiquettes de paniers à tablettes provenant de Mâri. In Symbolae ad Iura Orientis antiqui pertinentes Paulo Koschaeker dedicatae, ed. J. Friedrich, J. G. Lautner, and J. Miles. Pp. 119-20. Studia et Documenta ad Iura Orientis Antiqui pertinentia, 2. Leiden: E. J. Brill.

van der Toorn, K. 1996. Family Religion in Babylonia, Syria and Israel: Continuity and Change in the Forms of Religious Life. Leiden: E. J. Brill.

Tuchman, B. W. 1986. Biography as a Prism of History. In Oats 1986. Pp. 93-103.

Veenhof, K. R. 1992. makkārum, «trader»?. NABU 1992: 4 (no. 5).

Villard, P. 1992. Le Déplacement des trésors royaux, d'après les Archives royales de Mari. In La Circulation des biens, des personnes et des idées dans le Proche-Orient ancien, ed. D. Charpin and F. Joannès 1992. Pp. 195-205. Actes de la XXXVIII ${ }^{e}$ Rencontre assyriologique internationale, Paris, 8-10 juillet 1991. Paris: Éditions Recherche sur les Civilisations. 1994. Nomination d'un scheich. In Charpin and Durand 1994. Pp. 291-334.

Vincente, C. A. 1991. The 1987 Tell Leilan Tablets Dated by the Limmu of Habil-kinu. 2 vols. [Ph.D. Diss., Yale University.] Ann Arbor: University Microfilms [no. 9315202]. 